УДК [631.529:635.657, DOI 10.31210/visnyk2018.02.03

(C) 2018

Пузік В. К., доктор сільськогосподарських наук, професор, илен-кореспондент НААН Украӥни, заслужений діяч науки і техніки Украӥни, Тітова А. С., здобувач

Харківський національний аграрний університет ім. В. В. Докучаєва

\title{
КЛАСИФІКАЦІЯ ТА ВИДІЛЕННЯ ДЖЕРЕЛ ЯКІСНОГО СКЛАДУ ЗРАЗКІВ КОЛЕКЦІї НУТУ ЗА ВМІСТОМ БІЛКА ТА ОЛІЇ
}

\section{Рецензент - доктор сільськогосподарських наук, професор А. О. Рожков}

Узагальнено результати чотирирічних досліджень вивчення колекції нуту (Cicer L.) за біохімічним аналізом на вміст білка за методикою Кельдаля та вмістом олії за методикою Рушковського. Досліджено 30 зразків нуту семи видів - Cicer arientinum L., C. Reticulatum Labizinsky., C. Judaicum Boiss., C. bijugum K.N. Rech., C. Pinnatifidum Jaub., C. chorassinicum (Bge) M. Pop., C. Yamashitae Kitam. Проаналізовано особливості мінливості вмісту білка та олії в колекційних зразках у різні за погодними умовами роки вирощування нуту в зоні східного Лісостепу Украйни. Проведено структурний аналіз колекиії для виділення джерел високого вмісту білку та олії й подальшого створення нового вихідного матеріалу для селекиї нуту.

Ключові слова: нут (Cicer L.), біохімічний аналіз, білок, олія, зразки-донори.

Постановка проблеми. Вирішення проблем якісного харчування, збереження здоров'я та збільшення тривалості життя $\epsilon$ пріоритетними для більшості країн світу. Відсутність стратегічного підходу до розробки нових продуктів харчування, зокрема 3 високою харчовою та біологічною цінністю, зумовлює погіршення раціону харчування населення України.

Аналіз основних досліджень і публікацій, у яких започатковано розв'язання проблеми. Підвищення якості продуктів харчування можливе у випадку додавання до раціону нових видів рослинної сировини 3 вмістом комплексу білків, ліпідів, мінеральних речовин, вітамінів, 3 високими поживними, смаковими та лікувально-профілактичними властивостями [6]. Основним завданням селекції нуту є виведення сортів 3 підвищеною продуктивністю, які характеризуються високими смаковими якостями і підвищеним вмістом найбільш цінних амінокислот, стійких до грибкових, бактеріальних і вірусних хвороб, а також придатних до механізованого збирання.

Збалансований амінокислотний склад білків нуту зумовлює його високу біологічну цінність, так як за кількістю незамінних амінокислот у перерахунку на 100 г білка нут перевищує інші бобові культури. Порівняння амінокислотного складу бобових культур та яєчних продуктів свідчить, що за біологічною цінністю білки нуту наближені до білка яєць, особливо за метіоніном i триптофаном [13]. Білок нуту за амінокислотним складом наближається до ідеального за ФАО [14], тому ця культура може бути добрим замінником м'яса у переробній промисловості.

У зернівці нуту сконцентровано 23-32 \% повноцінного білка, 60-70\% крохмалю та 5-7\% олії, які перетравлюються на 87-97 \%. Серед мінеральних речовин у насінні містяться фосфор, калій, магній, молібден, марганець, залізо та інші. Зерно нуту має високу енергетичну цінність (100 г містить 334 ккал), високий вміст провітаміну А (в 100 г - 316 інтернаціональних одиниць каротину) $[5,6,12]$.

Нут містить 17 амінокислот, у тому числі 9 незамінних $[1,3]$. Низка хімічних елементів, що входять до складу нуту, наприклад, залізо, мідь, магній, цинк, марганець, здатні утворювати комплекси 3 речовинами органічної природи. Вони входять до складу або активують до 300 ферментів [11].

Мета досліджень: за допомогою біохімічного аналізу колекції нуту встановити мінливості вмісту білка та олії у колекційних зразків нуту.

Матеріали і методи досліджень. Польові досліди проводили на дослідному полі Харківського національного аграрного університету ім. В. В. Докучаєва у 2013-2016 рр. Об'єктом досліджень було 30 зразків нуту колекції Національного центру генетичних ресурсів рослин України (НЦГРРУ) семи видів - Cicer arientinum L., C. Reticulatum Labizinsky., C. Judaicum Boiss., C. bijugum K.N. Rech., C. Pinnatifidum Jaub., C. chorassinicum (Bge) M. Pop., C. Yamashitae Kitam. Зразки інтродуковані з різних екологогеографічних районів (Україна, Росія, Чехія, Грузія, Азербайджан, Туркменістан, Афганістан, Туреччина, Сирія, Іран, Індія, Португалія, Норвегія, Канада, США). 


\section{СІЛЬСЬКЕ ГОСПОДАРСТВО. РОСЛИННИЦТВО}

Сівбу проводили вручну, в кожний рядок висівали по 25 насінин. Площа ділянки $-1 \mathrm{~m}^{2}$. Використовували стандартне розміщення ділянок, i3 широкорядним способом сівби, 3 міжряддям 45 см. Польові досліди закладали та виконували згідно з методикою дослідної справи за Б. А. Доспєхова [4].

Протягом вегетаційного періоду уважно стежили за характером росту і розвитку рослин у відповідності до «Методики держсортовипробування сільськогосподарських культур» за Волкодавом В. В. [2]. Погодні умови визначали на підставі результатів метеостанції ХНАУ ім. В. В. Докучаєва, використовувались показники середньомісячної температури повітря, сума опадів за місяць, сума активних температур вище $10^{\circ} \mathrm{C}$ i гідротермічний коефіцієнт Селянінова (ГТК) [7, 8].

Досліджувана колекція висівалась протягом 2013-2016 рр. на дослідному полі Харківського національного аграрного університету ім. В. В. Докучаєва. Біохімічний аналіз колекції нуту проведено в лабораторії якості зерна Інституту рослинництва ім. В. Я. Юр’єва на вміст білка за методикою Кельдаля [9] 3 коефіцієнтом перерахунку для зернобобових 6,25 та вміст олії за методикою Рушковського [10].

Результати досліджень. Агрокліматичні умови у роки досліджень, описані нами за допомогою інтегрального показника (ГТК), були відмінними. Так, умови 2013 р. та 2015 р. за середнім ГТК періоду вегетації нуту (квітень серпень), відзначались посухою (ГТК $=0,73$ та 0,68 відповідно), а у 2014 р та 2016 p. оптимальним рівнем зволоженості (ГТК $=1,10$ та 1,06 ) відповідно. У роки 3 високим рівнем забезпечення вологою $(2014,2016)$ нут показав дещо нижчий вміст білка в зерні, в середньому по колекції даний показник становив 21,1 \% та 20,1 \% відповідно. У більш посушливі роки, такі як 2013-2015 рр., середній вміст білка становив $22,7 \%$ та 22,3 \% відповідно (табл. 1). Ця характерна особливість зернобобових культур дуже важлива в умовах посушливих років i нут, як культура 3 підвищеною посухостійкістю, стає важливим джерелом рослинного білка.

Отримані результати вмісту білка різних видів нуту показали, що у виду C. arientinum L. у 2013 році в середньому по зразках становив 23,3 \%, у 2014 році - 21,5\%, у 2015 році - 22,8 \%, у 2016 році - 20,5\%, середнє значення вмісту білка за чотири роки досліджень було 22,0 \%. У виду C. arientinum $L$. максимальній вміст білка був у зразків UD0500196 (Грузія) 26,8 \% та X 2001 173-18 (Канада) 25,7\%.

Вид C. reticulatum Labizinsky у 2013 році пока- зник вмісту білка був 22,8 \%, відповідно у 2014 році - 21,4\%, у 2015 році - 22,9 \%, у 2016 році $20,6 \%$, середнє значення вмісту білка за досліджуваний період становило 21,9\%.

Вид C. judaicum Boiss був представлений одним зразком із середнім вмістом білка по роках досліджень 20,7 \%.

У 2013 році у виду C. bijugum K.N. Rech вміст білка становив 22,6\%, у 2014 році - 21,3\%, у 2015 році - 22,3\%, у 2016 році - 20,4 \%. В середньому по роках $-21,7 \%$.

Вміст білка зразків виду C. pinnatifidum Jaub був у 2013 році в середньому по зразках - 19,0 \%, у 2014 році - 17,0 \%, у 2015 році - 18,3\%, у 2016 році - 17,0 \%, середнє значення за чотири роки досліджень було 17,8 \%.

Вид C. chorassinicum (Bge) M. Рор у 2013 році мав вміст білка 18,3\%, у 2014 році - 17,2 \%, у 2015 році - 19,5 \%, у 2016 році - 16,9\%, середнє значення вмісту білка за чотири роки досліджень було 18,0 \%.

У зразка виду C. yamashitae Kitam у 2013 році вміст білка був 24,9\%, у 2014 році - 23,4 \%, у 2015 році - 24,1 \%, у 2016 році - 20,6 \%, середнє значення вмісту білка за чотири роки досліджень було $23,3 \%$.

Нами були виділені зразки-донори високого вмісту білка: UD0500196 (Грузія) $(28,6$ \%) та X $2001^{\text {th }} 173-18$ (Канада) $(26,2 \%)$.

Основна частина колекції нуту мала середній вміст білка, який коливався у межах від 17,2 до $24,5 \%$.

Також виділено зразки з високою стабільністю показника по роках: найменше середньоквадратичне відхилення показника та коефіцієнт варіаціï були серед зразка культурного виду C. arientinum L. UD0500001 (Іран) $(\mathrm{S}=0,8 ; \mathrm{V}=$ $3,9 \%)$, серед шести диких видів зразок виду C. bijugum K.N. Rech. ICCW42 (Туреччина) ( $\mathrm{S}=$ 0,5; V = 2,1 \%). Коефіцієнт варіації по колекції за роки досліджень коливався від 2,1\% до 9,8 \%, що вказує на високу стабільність даної ознаки за роками досліджень (табл. 1).

За проведеним аналізом на вміст олії (за методикою Рушковського) зразків колекції нуту встановлено наступне: серед зразків виду Cicer arientinum L. у 2013 році в середньому по виду 5,5\%, у 2014 році - 6,1 \%, у 2015 році - 5,5\%, у 2016 році - 5,9\%, середнє значення вмісту олії за чотири роки досліджень було 5,8 \%.

Максимальний вміст олії по виду $C$. arientinum $L$. був у зразків СР 66-1 з Індії - 8,0 \%, зразка INIA 45 із Норвегіï - 7,1 \% та зразка Sierra із США $7,1 \%$. 
СІЛЬСЬКЕ ГОСПОДАРСТВО. РОСЛИННИЦТВО

\section{1. Вміст білка у зерні різних видів нуту}

\begin{tabular}{|c|c|c|c|c|c|c|c|c|}
\hline \multirow{2}{*}{$\begin{array}{l}\text { № національ- } \\
\text { ного каталогу }\end{array}$} & \multirow{2}{*}{ Назва зразка } & \multirow{2}{*}{ Походження } & \multicolumn{4}{|c|}{ Вміст білка у зерні } & \multirow{2}{*}{$\bar{X} \pm S \bar{X}$} & \multirow{2}{*}{$\mathrm{V}, \%$} \\
\hline & & & $2013 \mathrm{p}$. & $2014 \mathrm{p}$ & $2015 \mathrm{p}$. & $2016 \mathrm{p}$. & & \\
\hline & \multicolumn{8}{|c|}{ C. arientinum L. } \\
\hline UD0500102 & Луганець & $\begin{array}{c}\text { Україна Лу- } \\
\text { ганс.д.с. }\end{array}$ & 24,8 & 22,9 & 23,1 & 21,3 & $23,0 \pm 1,4$ & 6,2 \\
\hline UD0501163 & Тріумф & Україна СГЇ & 21,3 & 20,7 & 23,5 & 19,7 & $21,3 \pm 1,6$ & 7,6 \\
\hline UD0501164 & Пегас & Україна СГЇ & 25,1 & 23,1 & 24,8 & 21,1 & $23,5 \pm 1,8$ & 7,8 \\
\hline UD0501194 & Добробут & $\begin{array}{c}\text { Україна Лу- } \\
\text { ганс.д.с. }\end{array}$ & 21,8 & 20,2 & 21,1 & 18,9 & $20,5 \pm 1,3$ & 6,1 \\
\hline UD0500015 & Гибрид 25 & Росія & 19,4 & 18,5 & 19,3 & 15,6 & $18,2 \pm 1,8$ & 9,8 \\
\hline UD0500101 & $\begin{array}{l}\text { Краснокут- } \\
\text { ський } 123\end{array}$ & Росія & 23,1 & 20,4 & 22,6 & 21,0 & $21,8 \pm 1,3$ & 5,9 \\
\hline UD0500422 & $\begin{array}{c}\text { Cicer } \\
\text { rotundum }\end{array}$ & Чехія & 23,2 & 21,0 & 22,4 & 21,6 & $22,1 \pm 1,0$ & 4,3 \\
\hline UD0501550 & Flip 97-220c & Cunig & 19,3 & 17,2 & 20,1 & 17,9 & $18,6 \pm 1,3$ & 7,1 \\
\hline UD0501541 & Flip 00-20c & $\mathrm{C}$ & 20,7 & 18,7 & 19,3 & 17,6 & $19,1 \pm 1,3$ & 6,8 \\
\hline UD0501485 & NEC 1506 & Португалія & 23,1 & 19,8 & 20,6 & 20,1 & $20,9 \pm 1,5$ & 7,2 \\
\hline UD0501479 & INIA 45 & Норвегія & 24,3 & 22,2 & 23,6 & 21,3 & $22,9 \pm 1,4$ & 5,9 \\
\hline UD0500022 & - & Грузія & 28,6 & 26,5 & 27,1 & 24,9 & $26,8 \pm 1,5$ & 5,7 \\
\hline UD0500196 & - & Азербайджан & 23,4 & 21,2 & 22,5 & 20,8 & $22,0 \pm 1,2$ & 5,4 \\
\hline UD0502017 & - & Туркменістан & 25,1 & 23,7 & 24,1 & 21,9 & $23,7 \pm 1,3$ & 5,6 \\
\hline UD0501486 & NEC 1847 & Іран & 24,9 & 23,2 & 24,1 & 20,9 & $23,3 \pm 1,7$ & 7,4 \\
\hline UD0500001 & - & Іран & 22,1 & 20,6 & 21,5 & 20,3 & $21,1 \pm 0,8$ & 3,9 \\
\hline & CP 66 & & 9 & & & 16,8 & $8,2 \pm 1,1$ & 6,3 \\
\hline UD0501927 & $\begin{array}{l}X 2001^{\text {th }} \\
173-18\end{array}$ & Канада & 26,2 & 25,6 & 27,1 & 23,7 & $25,7 \pm 1,4$ & 5,6 \\
\hline 78 & Evans & & 25,6 & 23,5 & 24,9 & 22,1 & $4,0 \pm 1,6$ & 6,5 \\
\hline 751 & Sierra & США & 24,7 & 23,4 & 24,3 & 21,8 & $23,6 \pm 1,3$ & 5,5 \\
\hline \multicolumn{3}{|c|}{ Середнє по виду } & 23,3 & 21,5 & 22,8 & 20,5 & $22,0 \pm 1,3$ & 5,7 \\
\hline \multicolumn{9}{|c|}{ C. reticulatum Labizinsky } \\
\hline UD0501165 & ICCW 8 & Туреччина & 22,4 & 20,4 & 21,1 & 19,2 & $20,8 \pm 1,3$ & 6,4 \\
\hline UD0501669 & ICCW 9 & Туреччина & 23,1 & 22,4 & 24,7 & 21,9 & $23,0 \pm 1,2$ & 5,3 \\
\hline \multicolumn{3}{|c|}{ Середнє по виду } & 22,8 & 21,4 & 22,9 & 20,6 & $21,9 \pm 1,1$ & 5,1 \\
\hline \multicolumn{9}{|c|}{ C. judaicum Boiss } \\
\hline UD0501709 & ICCW 36 & Ізраїль & 21,7 & 20,1 & 21,5 & 19,4 & $\pm 1,1$ & 5,4 \\
\hline \multicolumn{3}{|c|}{ Середнє по виду } & 21,7 & 20,1 & 21,5 & 19,4 & $, 7 \pm 1,1$ & 5,4 \\
\hline \multicolumn{9}{|c|}{ C. bijugum K.N. Rech. } \\
\hline UD0502026 & ICCW 71 & Туреччина & 23,9 & 22,1 & 24,1 & 20,5 & $22,7 \pm 1,7$ & 7,5 \\
\hline UD0502028 & ICCW 42 & Туреччина & 25,1 & 24,2 & 24,6 & 23,9 & $24,5 \pm 0,5$ & 2,1 \\
\hline UD0500525 & ICCW 1 & Афганістан & 18,9 & 17,7 & 18,1 & 16,9 & $17,9 \pm 0,8$ & 4,7 \\
\hline \multicolumn{3}{|c|}{ Середнє по виду } & 22,6 & 21,3 & 22,3 & 20,4 & $21,7 \pm 1,0$ & 4,6 \\
\hline \multicolumn{9}{|c|}{ C. pinnatifidum Jaub. } \\
\hline 97 & ICCW 37 & чина & 19,3 & 17,0 & 8,4 & 17,8 & $18,1 \pm 1,0$ & 5,4 \\
\hline UD0501672 & ICCW 38 & Туреччина & 18,6 & 16,9 & 18,1 & 10,1 & $17,4 \pm 1,1$ & 6,5 \\
\hline \multicolumn{3}{|c|}{ Середнє по виду } & 19,0 & 17,0 & 18,3 & 17,0 & $17,8 \pm 1,0$ & 5,6 \\
\hline \multicolumn{9}{|c|}{ C. chorassinicum (Bge) M. Pop } \\
\hline UD0502027 & ICCW 26 & Афганістан & 18,3 & 17,2 & 19,5 & 16,9 & $18,0 \pm 1,2$ & 6,6 \\
\hline \multicolumn{3}{|c|}{ Середнє по виду } & 18,3 & 17,2 & 19,5 & 16,9 & $18,0 \pm 1,2$ & 6,6 \\
\hline
\end{tabular}


Продовження табл. 1

\begin{tabular}{|c|c|c|c|c|c|c|c|c|}
\hline \multirow{2}{*}{$\begin{array}{l}\text { № національ- } \\
\text { ного каталогу }\end{array}$} & \multirow{2}{*}{ Назва зразка } & \multirow{2}{*}{ Походження } & \multicolumn{4}{|c|}{ Вміст білка у зерні } & \multirow{2}{*}{$\bar{X} \pm S \bar{X}$} & \multirow{2}{*}{$\mathrm{V}, \%$} \\
\hline & & & $2013 \mathrm{p}$. & 2014 p. & $2015 \mathrm{p}$. & $2016 \mathrm{p}$. & & \\
\hline \multicolumn{9}{|c|}{ C. yamashitae Kitam } \\
\hline UD0501674 & ICCW 2 & Афганістан & 24,9 & 23,4 & 24,1 & 20,6 & $23,3 \pm 1,9$ & 8,0 \\
\hline \multicolumn{3}{|c|}{ Середнє по виду } & 24,9 & 23,4 & 24,1 & 20,6 & $23,3 \pm 1,9$ & 8,0 \\
\hline \multicolumn{3}{|c|}{ Середнє по колекції } & 22,7 & 21,1 & 22,3 & 20,1 & $21,2 \pm 1,2$ & 5,6 \\
\hline \multicolumn{3}{|c|}{ Стандартна помилка } & 0,5 & 0,5 & 0,5 & 0,5 & & \\
\hline \multicolumn{3}{|c|}{ Середньоквадратичне відхилення } & 2,7 & 2,6 & 2,6 & 2,3 & & \\
\hline \multicolumn{3}{|c|}{ Коефіцієнт варіації } & 11,7 & 12,5 & 11,7 & 11,6 & & \\
\hline
\end{tabular}

2. Вміст олії у зерні колекції різних видів нуту

\begin{tabular}{|c|c|c|c|c|c|c|c|c|}
\hline \multirow{2}{*}{$\begin{array}{l}\text { № національ- } \\
\text { ного каталогу }\end{array}$} & \multirow{2}{*}{ Назва зразка } & \multirow{2}{*}{ Походження } & \multicolumn{4}{|c|}{ Вміст олії у зерні } & \multirow{2}{*}{$\bar{X} \pm S \bar{X}$} & \multirow{2}{*}{$\mathrm{V}, \%$} \\
\hline & & & 2013 p. & 2014 p. & $2015 \mathrm{p}$. & $2016 \mathrm{p}$. & & \\
\hline & \multicolumn{8}{|c|}{ C. arientinum $L$. } \\
\hline UD0500102 & Луганець & $\begin{array}{c}\text { Україна } \\
\text { Луганс.д.с. }\end{array}$ & 4,3 & 4,9 & 4,2 & 4,7 & $4,5 \pm 0,3$ & 7,3 \\
\hline UD0501163 & Тріумф & Україна СГї & 4,8 & 5,8 & 5,2 & 5,4 & $5,3 \pm 0,4$ & 7,9 \\
\hline UD0501164 & Пегас & Україна СГї & 5,1 & 5,5 & 4,9 & 5,7 & $5,3 \pm 0,4$ & 6,9 \\
\hline UD0501194 & Добробут & $\begin{array}{c}\text { Україна } \\
\text { Луганс.д.с. }\end{array}$ & 6,1 & 6,4 & 5,7 & 6,6 & $6,2 \pm 0,4$ & 6,3 \\
\hline UD0500015 & Гибрид 25 & Рociя & 5,9 & 6,5 & 5,6 & 6,0 & $6,0 \pm 0,4$ & 6,2 \\
\hline UD0500101 & $\begin{array}{l}\text { Краснокут- } \\
\text { ський } 123\end{array}$ & Росія & 5,1 & 5,7 & 5,3 & 5,9 & $5,5 \pm 0,4$ & 6,6 \\
\hline UD0500422 & $\begin{array}{c}\text { Cicer } \\
\text { rotundum }\end{array}$ & Чехія & 5,2 & 5,6 & 4,9 & 5,5 & $5,3 \pm 0,3$ & 6,0 \\
\hline UD0501550 & Flip 97-220c & Сирія & 6,1 & 6,5 & 5,9 & 6,2 & $6,2 \pm 0,3$ & 4,0 \\
\hline UD0501541 & Flip 00-20c & Сирія & 5,9 & 6,4 & 6,1 & 6,5 & $6,2 \pm 0,3$ & 4,4 \\
\hline UD0501485 & NEC 1506 & Португалія & 5,7 & 6,7 & 5,9 & 6,2 & $6,1 \pm 0,4$ & 7,1 \\
\hline UD0501479 & INIA 45 & Норвегія & 6,5 & 7,1 & 6,3 & 6,8 & $6,7 \pm 0,4$ & 5,2 \\
\hline UD0500022 & - & Грузія & 3,3 & 3,4 & 3,1 & 2,9 & $3,2 \pm 0,2$ & 7,0 \\
\hline UD0500196 & - & $\begin{array}{c}\text { Азербай- } \\
\text { джан }\end{array}$ & 5,8 & 6,4 & 5,9 & 6,6 & $6,2 \pm 0,4$ & 6,3 \\
\hline UD0502017 & - & $\begin{array}{c}\text { Туркменіс- } \\
\text { тан }\end{array}$ & 5,4 & 6,4 & 5,6 & 5,9 & $5,8 \pm 0,4$ & 7,5 \\
\hline UD0501486 & NEC 1847 & Іран & 5,1 & 5,5 & 4,9 & 5,2 & $5,2 \pm 0,3$ & 4,8 \\
\hline UD0500001 & - & Іран & 4,7 & 5,2 & 4,8 & 5,0 & $4,9 \pm 0,2$ & 4,5 \\
\hline UD0500980 & CP 66-1 & Індія & 7,2 & 8,0 & 7,3 & 7,7 & $7,6 \pm 0,4$ & 4,9 \\
\hline UD0501927 & $\begin{array}{l}X 2001^{\text {th }} \\
173-18\end{array}$ & Канада & 5,5 & 6,6 & 5,8 & 6,3 & $6,1 \pm 0,5$ & 8,2 \\
\hline UD0501678 & Evans & США & 6,1 & 6,9 & 5,6 & 6,5 & $6,3 \pm 0,6$ & 8,9 \\
\hline UD0501751 & Sierra & США & 6,3 & 7,1 & 6,6 & 7,0 & $6,8 \pm 0,4$ & 5,5 \\
\hline \multicolumn{3}{|c|}{ Середнє по виду } & 5,5 & 6,1 & 5,5 & 5,9 & $5,8 \pm 0,3$ & 5,6 \\
\hline \multicolumn{9}{|c|}{ C. reticulatum Labizinsky } \\
\hline UD0501165 & ICCW 8 & Туреччина & 5,3 & 5,8 & 5,1 & 5,6 & $5,5 \pm 0,3$ & 5,7 \\
\hline UD0501669 & ICCW 9 & Туреччина & 4,6 & 5,1 & 4,8 & 5,2 & $4,9 \pm 0,3$ & 5,6 \\
\hline \multicolumn{3}{|c|}{ Середнє по виду } & 5,0 & 5,5 & 5,0 & 5,4 & $5,2 \pm 0,3$ & 5,3 \\
\hline \multicolumn{9}{|c|}{ C. judaicum Boiss } \\
\hline UD0501709 & ICCW 36 & Ізраїль & 4,4 & 5,1 & 4,6 & 5,0 & $4,8 \pm 0,3$ & 6,9 \\
\hline \multicolumn{3}{|c|}{ Середнє по виду } & 4,4 & 5,1 & 4,6 & 5,0 & $4,8 \pm 0,3$ & 6,9 \\
\hline
\end{tabular}


Продовження табл. 2

\begin{tabular}{|c|c|c|c|c|c|c|c|c|}
\hline \multirow{2}{*}{$\begin{array}{l}\text { № національ- } \\
\text { ного каталогу }\end{array}$} & \multirow{2}{*}{ Назва зразка } & \multirow{2}{*}{ Походження } & \multicolumn{4}{|c|}{ Вміст олії у зерні } & \multirow{2}{*}{$\bar{X} \pm S \bar{X}$} & \multirow{2}{*}{$\mathrm{V}, \%$} \\
\hline & & & $2013 \mathrm{p}$. & $2014 \mathrm{p}$. & $2015 \mathrm{p}$. & $2016 \mathrm{p}$. & & \\
\hline \multicolumn{9}{|c|}{ C. bijugum K.N. Rech. } \\
\hline UD0502026 & ICCW 71 & Туреччина & 5,2 & 5,8 & 5,1 & 5,6 & $5,4 \pm 0,3$ & 6,1 \\
\hline UD0502028 & ICCW 42 & Туреччина & 3,3 & 3,7 & 3,1 & 3,6 & $3,4 \pm 0,3$ & 8,0 \\
\hline UD0500525 & ICCW 1 & Афганістан & 3,6 & 4,1 & 3,8 & 3,9 & $3,9 \pm 0,2$ & 5,4 \\
\hline \multicolumn{3}{|c|}{ Середнє по виду } & 4,0 & 4,5 & 4,0 & 4,4 & $4,2 \pm 0,3$ & 6,1 \\
\hline \multicolumn{9}{|c|}{ C. pinnatifidum Jaub. } \\
\hline UD0501197 & ICCW 37 & Туреччина & 4,2 & 4,6 & 3,9 & 4,4 & $4,3 \pm 0,3$ & 7,0 \\
\hline UD0501672 & ICCW 38 & Туреччина & 3,9 & 4,3 & 3,8 & 4,0 & $4,0 \pm 0,2$ & 5,4 \\
\hline \multicolumn{3}{|c|}{ Середнє по виду } & 4,1 & 4,5 & 3,9 & 4,2 & $4,1 \pm 0,3$ & 6,1 \\
\hline \multicolumn{9}{|c|}{ C. chorassinicum (Bge) M. Pop } \\
\hline UD0502027 & ICCW 26 & Афганістан & 4,2 & 4,7 & 4,1 & 4,5 & $4,4 \pm 0,3$ & 6,3 \\
\hline \multicolumn{3}{|c|}{ Середнє по виду } & 4,2 & 4,7 & 4,1 & 4,5 & $4,4 \pm 0,3$ & 6,3 \\
\hline \multicolumn{9}{|c|}{ C. yamashitae Kitam } \\
\hline UD0501674 & ICCW 2 & Афганістан & 4,1 & 4,7 & 4,3 & 4,5 & $4,4 \pm 0,3$ & 5,9 \\
\hline \multicolumn{3}{|c|}{ Середнє по виду } & 4,1 & 4,7 & 4,3 & 4,5 & $4,4 \pm 0,3$ & 5,9 \\
\hline \multicolumn{3}{|c|}{ Середнє по колекції } & 5,1 & 5,7 & 5,1 & 5,5 & $5,3 \pm 0,3$ & 5,6 \\
\hline \multicolumn{3}{|c|}{ Стандартна помилка } & 0,2 & 0,2 & 0,2 & 0,2 & & \\
\hline \multicolumn{3}{|c|}{ Середньоквадратичне відхилення } & 1,0 & 1,1 & 1,0 & 1,1 & & \\
\hline \multicolumn{3}{|c|}{ Коефіцієнт варіації } & 19,2 & 19,2 & 19,7 & 20,0 & & \\
\hline
\end{tabular}

У виду C. reticulatum Labizinsky у 2013 році вміст олії був $5,0 \%$, у 2014 році - 5,5\%, у 2015 році $-5,0 \%$, у 2016 році $-5,4 \%$, середнє значення вмісту олії за чотири роки досліджень було 5,2 \%. Вид C. judaicum Boiss у 2013 році мав $4,4 \%$, у 2014 році - 5,1\%, у 2015 році - 4,6 \%, у 2016 році $-5,0 \%$, середнє значення за чотири роки досліджень $-4,8 \%$.

У 2013 у виду C. bijugum K.N. Rech вміст олії становив $4,0 \%$, у 2014 році $-4,5 \%$, у 2015 році$4,0 \%$, у 2016 році $-4,4 \%$. У середньому по роках $-4,2 \%$.

Вміст олії зразків виду C. pinnatifidum Jaub був у 2013 році в середньому по зразках $-4,1 \%$, у 2014 році $-4,5 \%$, у 2015 році - 3,9\%, у 2016 році $-4,2 \%$, середнє значення за чотири роки досліджень було $4,1 \%$. Вид C. chorassinicum (Bge) M. Рор у 2013 році мав вміст олії 4,2 \%, у 2014 році $-4,7 \%$, у 2015 році - 4,1\%, у 2016 році $-4,5 \%$, середне значення вмісту олії за чотири роки досліджень становило 4,4\%. У виду C. yamashitae Kitam у 2013 році вміст олії був $4,1 \%$, у 2014 році - 4,7\%, у 2015 році - 4,3\%, у 2016 році - 4,5\%, середнє значення вмісту білка за чотири роки досліджень було $4,4 \%$.

Загалом вміст олії по колекції протягом 20132016 років варіював у межах 5,1-5,5\%, середнє значення показника за чотири роки досліджень було $5,3 \%$.
Нами були виділені зразки-донори високого вмісту олії: зразки СР 66-1 з Індії $(8,0 \%)$ та зразок Sierra із США (7,1\%), INIA 45 (Норвегія) (7,1\%).

Також виділено зразки з високою стабільністю показника за роками: найменше середньоквадратичне відхилення показника та коефіцієнт варіації були у зразка культурного виду C. arientinum $L$. Flip 97-220c (Сирія) ( $\mathrm{S}=0,3 ; \mathrm{V}=4,0 \%$ ), серед шести диких видів зразок виду C. bijugum K.N. Rech. ICCW1 (Афганістан) (S=0,2; V=5,4 \%). Коефіцієнт варіації по колекції за роки досліджень знаходився в межах від 4,0 \% до 8,9\%, що вказує на високу стабільність даної ознаки за роками досліджень (табл. 2).

Висновок. Проведений нами аналіз колекції нуту за біохімічними показниками (вмістом білка та олії в зерні) дав змогу структурувати колекцію, виділити джерела високого вмісту даних речовин із метою підбору батьківських форм для схрещування та створення на їх основі нового вихідного матеріалу для селекції культури. За вмістом білка зразками-донорами є UD0500196 $(28,6 \%)$ та X $2001^{\text {th }} 173-18(26,2 \%)$; за вмістом олії зразками-донорами стали СР 66-1 (8,0 \%) та зразки Sierra $(7,1 \%)$, INIA 45 (7,1\%). Вміст білка та олії в колекційних зразках нуту залежить від сорту і погодних умов. 


\section{БІБЛІОГРАФІЯ}

1. Берестова С. І. Вивчення амінокислотного складу Humulus lupulus L. // Фармаком, 2006, №4. - С. 67-70.

2. Волкодав В. В. Методика державного сортовипробування сільськогосподарських культур. - K., 2000. $-100 \mathrm{c}$.

3. Губський Ю. I. Біологічна хімія. - КиївТернопіль : Укрмед книга, 2000. - 508 с.

4. Доспехов Б. А. Методика полевого опыта (с основами статистической обработки результатов исследований) // Агропромиздат. - М., 1985. -351 с.

5. Каленська С. М. Формування врожаю нуту під впливом елементів технології вирощування // Вісник ПДАА. - 2012, №2. - С. 21-25.

6. Кориунова Г. Ф. Обгрунтування режимів замочування бобів нуту для пророщування. ДонДУЕТ, 2013. - С. 249-254.

7. Образиова 3. Г. Практикум з агрометеорології част. 2. Агрометеорологічні характеристики та прогнози // Харк. держ. аграр. ун-т. - Х., 1998. $-34 \mathrm{c}$.

\section{ANNOTATION}

Puzik V. K., Titova A. E. Classification and separation of sources of qualitative composition of chick-pea collections by the content of protein and olive.

The results of four-year studies of chick-pea (Cicer L.) collection (the biochemical analysis of the protein content according to Kel'dall's method and the oil content according to Rushkovsky's method) are summarized. 30 samples of chick-pea, 7 species - Cicer arientinum L., C. Reticulatum Labizinsky, C. Judaicum Boiss, C. bilugum K.N. Rech., C. Pinnatifidum Jaub., C. chorassinicum (Bge) M. Pop., C. Yamashitae Kitam are studied. The features of protein and oil content variability in the collection samples under different weather conditions during the years of chick-pea growth in the Eastern Forest-Steppe of Ukraine are analyzed. A structural analysis of the collection was carried out for isolation the sources of high protein and oil content with the view of the further creation of a new base line for chick-pea breeding.

Samples with high stability of protein content by years were single out: the least standard deviation of the index and the coefficient of variation were among the cultivar C. arientinum L. UD0500001 (Iran), among the six wild species the same characteristics occur in the case of the species C. bilugum K. N. Rech ICCW42 (Turkey). The coefficient of variation in the collection over the
8. Павлова М. Д. Практикум по агрометеорологии //Л. : Гидрометеоиздат, 1984. - С. 110-121.

9. Прохорова М. И. Методы биохимических исследований. - Л. : Химия, 1982. -272 с.

10. Рушковский С. В. Методика химических исследований при селекции масличных растений. - М. : Пищепромиздат, 1947. - 99 с.

11. Скальный А. В. Биоэлементы в медицине // М. : Мир, 2004. -272 c.

12. Холод С. М., Холод С. Г., Іллічов Ю. Г. Нут - перспективна зернобобова культура для Лісостепу України // Вісник ПДАА. - 2013, №2. - C. 49-54.

13. Холодова О. Ю. Характеристика поживних властивостей нуту та сучасний стан його використання у харчовій промисловості // Товарознавство та інновації. - 2011, №3. - С. 165-170.

14. Химия и биохимия бобовых культур / под ред. М. Н. Запрометова // М. : Агропромиздат, 1986. - 335 c.

research years ranged from $2.1 \%$ to $9.8 \%$, which indicates the high stability of this feature in terms of research years. Donor samples of high content of oil have been single out. In years with wet weather the protein content is lower than that of years with arid weather in all collection samples. We took notice of samples value that showed a relatively high level of protein or oil on average over the research years. Such samples can be considered as a source of high content of protein or oil in the conditions of the Eastern Forest-Steppe zone of Ukraine. The main task of chick-pea breeding is to produce varieties with increased productivity, which are characterized by high taste and high content of the most valuable amino acids, resistant to fungal, bacterial and viral diseases, and also suitable for mechanized harvesting. Study of the source material for breeding under different environmental conditions allows to establish the rate of reaction of different genotypes to these conditions more accurately and makes it possible to prognosis their practical use. An integrated approach to breeding is a modern requirement for the creation of varieties not with one, but with a number of signs resistant to environmental conditions. Chick-pea is an important leguminous culture with high protein content, which is important for a balanced diet of humans.

Key words: chickpeas (Cicer L.), biochemical analysis, protein, oil, donor specimens. 